\title{
CAN WE ENHANCE DURABLE RESISTANCE AGAINST PLASMOPARA HALSTEDII (SUNFLOWER DOWNY MILDEW)?
}

\author{
Nachaat Sakr ${ }^{1,2 *}$ \\ ${ }^{1}$ INRA-UBP, UMR 1095, 234 Avenue du Brézet, 63100 Clermont-Ferrand, France \\ ${ }^{2}$ Present address: Department of Agriculture, Syrian Atomic Energy Commission, Damascus, P.O. Box 6091, Syria
}

Received: December 12, 2008

Accepted: August 7, 2009

\begin{abstract}
Sunflower downy mildew caused by Plasmopara halstedii is one of the most potentially important diseases. So far, a complete, major gene resistance $(P l)$ has been used successfully, but with the appearance of eight races in France since 2000, research on more durable resistance was undertaken. In this study, we present new results concerning the evolution of pathogenicity of $P$. halstedii under conditions of re-enforced infection and different $P l$ gene selection pressures. Moreover, we imagine the evolution of virulence and aggressiveness of $P$. halstedii under a mixture model of sunflower inbred lines carrying the two types of resistance which may enhance durable resistance against it. Examples of host-parasite interactions including the influence of plant mixture models against pathogens are equally presented to understand how the pathogen develops its pathogenicicity.
\end{abstract}

Key words: aggressiveness, major gene $P l$, pathogen evolution, super race

\section{INTRODUCTION}

For their survival, plants are obligated to maintain a continual surveillance against pathogens. The plants and their pathogens are engaged in a battle without end in order to better adaptation in a given environment (McDonald and Linde 2002). Within vegetal species, some genotypes are susceptible, the pathogen invades the plant and relationship is compatible. However, the others are resistant, the plants resist and relationship is incompatible (Parlevliet 2002). The association of different resistance sources within the same plant permit to enhance its durability against pathogens (Mundt 2002). In this study, we use terms according to the definitions of Van der Plank (1968). Aggressiveness is used to indicate the quantitative component of pathogenicity that is expressed horizontally irrespective of plant cultivars or species. Virulence is used to indicate the qualitative component of pathogenicity that is expressed vertically. Pathogenicity is used as a general term indicating an ability to cause disease symptoms.

This mini-review presents results concerning several studies of host-parasite interactions and plant mixture models against pathogens that affect durable resistance. New results concerning the evolution of pathogenicity in $P$. halstedii which is multiplied under several methods of $P l$ genes management are presented equally (Sakr 2008; Sakr et al. 2008c). From these examples, we propose a mixture model against $P$. halstedii (sunflower downy mildew), by using an association of sunflower inbred lines carrying major genes (Radwan et al. 2002; Dussle et al. 2004) and quantitative resistance newly discovered (Vear et al.
2007; Tourvieille de Labrouhe et al. 2008). In this model, we imagine the evolution of virulence and aggressiveness of pathogen under the conditions of sunflower mixture plants, which may enhance durable resistance. We need such studies because sunflower downy mildew has been controlled in France until mid 90 by using a complete, major gene resistance $(P l)$ according to Tourvieille de Labrouhe et al. (2005).

\section{Durable resistance}

The importance of resistance for controlling disease has frequently been demonstrated in agricultural systems (Wolfe 1985; McDonald and Linde 2002; Mundt 2002; Burdon et al. 2006). Van der Plank (1968) postulated that disease resistance in plants can be classed in one of two categories 1 - vertical resistance (race specific, qualitative resistance) which is conferred by major specific genes and tends to produce a disease-free plant. Vertical resistance is generally unstable, because resistance genes are quickly overcome by compatible races in the pathogen population, and too short-lived to be considered durable and 2 - horizontal resistance (partial, field, non race specific, or quantitative resistance) which is controlled by minor genes and tends to impact the rate of disease development (rate reducing) rather than produce a disease-free plant. Horizontal resistance is generally more stable and equally active against many races of pathogen. However, vertical resistance is not durable due to the result of rapid changes in the pathogen (Leach et al. 2001).

Durable resistance is a long - sought goal of crop production and plant breeding programmes. Johnson (1984) 
defined it as a resistant that remains effective while being extensively used in agriculture for a long period in an environment conductive to the disease. Major gene resistance durability is affected by the evolutionary potential of pathogen populations. Several factors intervening pathogen evolution are: the mutation, the genetic drift, gene flow, reproduction system and the selection (McDonald and Linde 2002). Selection by hosts probably plays the most prominent role among evolutionary forces shaping pathogen populations structures (McDonald and Linde 2002; Montarry et al. 2006), and it is also the force that can be best manipulated by man, through plant breeding and cultivar deployment (Palumbi 2001). Limited durability of the resistance, however, remains a major problem in the deployment of resistant cultivars (Van den Bosch and Gilligan 2003).

There are some cases demonstrating that a single $R$ gene can conifer highly durable resistance. Resistance to wheat leaf rust, caused by Puccinia triticina that is conditioned by the single adult plant resistance gene $\operatorname{Lr} 34$ has provided highly effective control for more than 30 years in North America (Kolmer 1993). Moreover, the gene Vf from Malus floribunda 821 for resistance to scab (Venturia inaequalis) has been used successfully for 50 years in apple breeding programmes (Parisi et al. 1993). Others are remarkably ephemeral, for example, $Y r 17$ for the control of yellow rust on wheat was rapidly overcome in two to three seasons by virulent isolates of $P$. striiformis f. sp. tritici in the UK followed by Denmark, France and Germany (Bayles et al. 2000).

The co-evolution between the pathogens and host plants suggests the development of existent and inherited tools to improve adaptation in a given environment. Host plant possess the two types of resistance: vertical and horizontal. Pathogens have an evolutionary potential that may intervene in their adaptation for the two types of resistance. A high level of mutation, a grand genetic variability, a high level of gene flow, a mixed system of reproduction and rapid reaction to selection pressure increase evolution capacity of pathogens against their host plants (McDonald and Linde 2002). However, there is evidence that resistance durability can be enhanced by using a mixture of plants (Mundt 2002).

\section{Host-Plant mixture against pathogens}

In natural systems, Knops et al. (1999) found a negative relationship between levels of foliar fungal and species richness. However, the use of mixtures in the agricultural situation is that mimic them where disease is often less apparent (Thrall and Burdon 2000). Mundt (2002) defined the mixture as association of plants which differ in their reaction to a pathogen and that reduce disease severity. Although individual plants might be susceptible to a component of the pathogen population, the host mixture as a whole develops a significant resistance level resulting mainly from host diversification (Wolfe 1985; Lannou et al. 2005). Host diversification using different resistance levels of plants against a given pathogen (Finckh and Wolfe 1998; Mundt 2002). Several studies showed a positive correlation between host-plant diversity and resistance to pathogen (Wolfe 1985; Thrall and Burdon
2000; Zhu et al. 2000). Agricultural systems involving the use of varietal mixtures have repeatedly demonstrated the linkage between host and pathogen genetic structure and the capacity of a diversified host population, albeit limited and artificial, to reduce disease severity and consequent pathogen-induced selection (Wolfe 1985; Zhu et al. 2000; Burdon et al. 2006). Diseased levels in mixtures are typically $10-70 \%$ of incidence levels seen in pure lines of their components (Burdon 1987). Moreover, Smithson and Lenne (1996) noted disease reductions relative to pure stands ranging from $4 \%$ to $89 \%$. However, not all mixtures lead to disease reduction (Groenewegegen and Zadoks 1979).

In a mixture of cultivars with different resistant genes, pathogens are restricted to susceptible hosts and spore losses on resistant plants results in considerable reduction in disease severity (Lannou 2001). A resistance gene deployed in a mixture will have less exposure to the pathogen population than if the same gene was deployed in monoculture of the same total crop area (de VallavieillePope 2004). This would be expected to reduce selection pressure and increase durability of that gene, limited field observations seem to support this view (Mundt 2002).

All the responses of pathogen populations to host mixtures are based on the competition between simple pathotypes, which have greater specificity on one of the host genotypes, but are unable to develop on several other hosts, and complex race (super race according to Robinson 1976) which are able to develop on several host genotypes, but have a fitness disadvantage related to the number of virulence they carry (Lannou 2001; Thrall and Burdon 2002; Lannou et al. 2005).

The majority of researches have been interested to measure the effect of plant mixture in rusts and powdery mildew pathosystems (Mundt 2002). However, a little observation has been worked on the downy mildews and particularly in the case of sunflower downy mildew according to Tourvieille de Labrouhe et al. (2005).

\section{P. halstedii is a model for physiological races development}

Sunflower downy mildew is a common disease in many regions of the world where sunflowers (Helianthus annuus L.) are grown. The pathogen, $P$. halstedii (Farlow) Berles \& de Toni, is an obligate parasite. The disease affects young plants when the water content of the soil is high and the maximum temperature is between 15 and $18^{\circ} \mathrm{C}$. P. halstedii is an Oomycete with asexual multiplication by liberation of zoosporangia produced under surfaces of sunflower leaves and sexual reproduction giving oospores which are found in crop residues.

$P$. halstedii is present in most areas of the world where sunflower is grown. It shows physiological races (pathotypes) capable of infecting a variable range of sunflower genotypes. The nomenclature of these races is based on the reaction of a series of differential lines (Tourvieille de Labrouhe 1999). Race specific resistance is controlled by major genes, denoted $\mathrm{Pl}$. Pathogen - specific recognition occurs following a gene-for-gene model (Radwan et al. 2002), which predicted that the outcome of the interaction is disease resistance when corresponding $R$ and Avr genes are present in both host plant and pathogen. In all 
other cases, plants do not sense pathogens and disease results (Flor 1971).

In France, race 100 (European race) has been presented in the sunflower crop since 1965. Until 1987 it was the only race identified, but in 1988 and 1989, two new races namely 710 and 703 appeared (Tourvieille de Labrouhe et al. 2005). Since then, prospecting each year have demonstrated the existence in France of 3 races in 1993, 5 races in 1994, 6 in 2000, 9 in 2002 and 12 in 2004 (Tourvieille de Labrouhe et al. 2005). The 8 races identified since 2000 $(304,307,314,334,704,707,714$ and 717$)$ and purified on specific host differentials had not been described previously in other countries. They appear to result from evolution of the parasite in France. This evolution seems to be linked with a quasi-exclusive use of Pl6 gene from 1990 which have been overcome by the parasite races 704 and 714. The late use of another gene Pl5 lead to an apparition of new virulence 334 (Tourvieille de Labrouhe et al. 2005). This apparition lead to intense the use of cluster Pl5/Pl8 in sunflower zones cultivated. The life period of $P l$ gene seems to be very short from its important use on a large soil. However, Gulya (2007) reported 35 races in different parts of the world.

In 1971, Vear and Leclercq suggested to cumulate maximum resistance genes in one genotype in order to avoid the break-down of the resistance by a new race of downy mildew. The French experimentation (Tourvieille de Labrouhe et al. 2005) showed that if this strategy did not accompany by complementary agronomic measure (rotation) or genetic measure (quantitative resistance); it will lead to formation a new virulence. In these conditions, the life period of $\mathrm{Pl}$ gene is inferior to 10 years. The rapid evolution of virulence observed in France attributed to deploy the same genes used in this experimentation (Tourvieille de Labrouhe et al. 2005). However, the same authors showed that whatever was the method of management (mixture, alternation, and monoculture) of $\mathrm{Pl}$ genes, their selection pressure led to the appearance of a new virulence.

\section{Mixture model}

The dilution of pathogen inoculum that occurs due to increased distance between plants of the same genotype appears the most important mechanism to increase durable resistance in genotype mixture against pathogens (Wolfe 1985; Mundt 2002).

Theoretically, host-diversity effects in mixtures of cultivars are both maximized when one host genotype expresses differential (qualitative) resistance to pathogen races, because such a genotype acts as a completely resistant host to avirulent fraction of the pathogen population (Garrett and Mundt 1999) and with various levels of quantitative resistance shown the potential to reduce disease severity (Garrett et al. 2001; Andrivon et al. 2003).

In sunflower downy mildew, our experimental model is to make a mixture of plants carrying vertical and horizontal resistances in a given environment, by respecting these two points:

1. Use of sunflower inbred lines carrying resistance genes correspond to avirulence genes in $P$. halstedii such as Pl8 or PlARg (Radwan et al. 2002; Dussle et al. 2004) which prevent the dispersion of pathogen among plants in the field, and

2. Use of sunflower inbred lines carrying highly and moderately horizontal resistance (Vear et al. 2007; Tourvieille de Labrouhe et al. 2008) which decrease quantity of pathogen.

This strategy supposes that pathogen would develop slowly on sunflower genotypes carrying horizontal resistance and genotypes carrying vertical resistance would limit fungal capacity to disperse on another mixture plants.

\section{Rate of fungal pathogenicity evolution depends on:}

The stability of the mixture's resistance depends on the ability of the pathogen populations to evolve their pathogenicity including virulence and aggressiveness (Lannou and Mundt 1996; Lannou 2001; Lannou et al. 2005; Sacristan and Garcia-Arenal 2008). Virulence is a driving force in host-pathogen co-evolution since it enables pathogen to overcome qualitative resistance genes $R$. Aggressiveness enables the pathogen to develop within the host plant (Van der Plank 1968; Robinson 1976). P. halstedii represents a case of pathogen with a high level of variability (Albourie et al. 1998; Spring and Haas 2002; Gulya 2007; Sakr et al. 2007; Delmotte et al., 2008; Komjati et al., 2008; Sakr 2008; Sakr et al., 2008a; Sakr et al. 2008a, 2009b) which may help to increase its evolutionary potential.

\section{Fungus ability to develop more virulent strains}

Super race alters its Avr factors to avoid $R$-dependant recognition and this mechanism determines Avr factors evolution (Sacristan and Garcia-Arenal 2008). However, direct recognition of $A v r$ by $R$ can lead to relatively rapid evolution of new virulence phenotypes by alteration of the Avr structure (Van der Hoorn et al. 2002). For a given pathogen, the breakdown of $R$ gene resistance can be obtained by a mutation of avirulence gene. This can vary from a mutation at nucleotide-level (Joosten et al. 1994) to a complete deletion of the avirulence gene (Joosten and de Wit 1999). Gout et al. (2007) showed that the gain of virulence was linked to a $260 \mathrm{~kb}$ deletion of a chromosomal segment spanning AvrLm1 in Leptoshaeria maculans. The selection of super race depends on the environment, host genotypes presented in the mixture, fungal capacity to develop new mechanisms for spore dispersion and finally the genetic background of super race (Mundt 2002; Lannou et al. 2005). However, it is more difficult to determine the selective influence of mixtures for clonal pathogens because virulence genes will not be randomly associated with other genes that influence pathogen fitness (Leach et al. 2001).

The aggressiveness of super race is weaker than a simple race that overcomes a limited number of vertical resistance genes (Robinson 1976; Lannou and Mundt 1996; Lannou 2001). Our results (Sakr 2008) show that the strain (super race) of virulence profile 714 in $P$. halstedii appeared in sunflower parcels (Tourvieille de Labrouhe et al. 2005) was more virulent and less aggressive than the strain (parent race) of profile virulence 100 (Table 1). In similar conditions, Murakami et al. (2007) found the same case in the pathosystem Magnaporthe oryzae the wheat and 
Table 1. Responses of P. halstedii strains to sunflower inbred lines ${ }^{v}$

\begin{tabular}{|c|c|c|c|}
\hline \multirow[b]{2}{*}{ P. halstedii strains } & \multicolumn{3}{|c|}{ Aggressiveness criteria } \\
\hline & latent period ${ }^{\mathrm{w}}[\mathrm{days}]^{*}$ & $\begin{array}{l}\text { sporulation density } \\
\text { [zoosporangia per } \\
\text { cotyledon] }^{*}\end{array}$ & $\begin{array}{l}\text { hypocotyl length }{ }^{y} \\
{[\mathrm{~mm}]^{*}}\end{array}$ \\
\hline Strain (parent race) of virulence profile 100 & $8.51 \mathrm{~b}$ & $1772.7510^{3} \mathrm{a}$ & $28.97 \mathrm{a}$ \\
\hline Strain (parent race) of virulence profile 710 & $9.56 \mathrm{a}$ & $764.2510^{3} \mathrm{~b}$ & $28.92 \mathrm{a}$ \\
\hline Strain (super race) of virulence profile 714 & $9.82 \mathrm{a}$ & $810.0010^{3} \mathrm{~b}$ & $29.29 \mathrm{a}$ \\
\hline Populations obtained from parcels $(13.51 \%)^{\mathrm{z}}$ & $8.48 \mathrm{~b}$ & $959.5010^{3} \mathrm{a}$ & $29.96 \mathrm{~b}$ \\
\hline Populations obtained from parcels $(5.88 \%)^{\mathrm{z}}$ & $8.77 \mathrm{a}$ & $732.0010^{3} \mathrm{~b}$ & 34.69 a \\
\hline
\end{tabular}

* values in the column with a letter in common are not significantly different according to Newman-Keuls ( $p=0.05)$

${ }^{v}$ aggressiveness measured on two sunflower inbred lines FU (highly resistant) and BT (moderately resistant)

${ }^{w}$ latent period: the number of days of incubation period necessary to obtain $80 \%$ of sporulating plants

x sporulation density: number of zoosporangia produced by a cotyledon

y hypocotyl length: corresponds to the distance from the stem base to cotyledon insertion which measured after 13 days incubation on diseased plants that showing sporulation on the shoot

z $\%$ of diseased plants in parcels which are taken from $P$. halstedii strains

Table 2. Characterization of the virulence of strains (parent races and super race) of $P$. halstedii

\begin{tabular}{|c|c|c|c|c|c|c|c|c|c|c|}
\hline \multirow{2}{*}{\begin{tabular}{c} 
Strains \\
\cline { 3 - 12 }
\end{tabular}} & Race & $\begin{array}{c}\text { D1 } \\
\text { Ha-304 }\end{array}$ & $\begin{array}{c}\text { D2 } \\
\text { Rha-265 }\end{array}$ & $\begin{array}{c}\text { D3 } \\
\text { Rha-274 }\end{array}$ & $\begin{array}{c}\text { D4 } \\
\text { PMI3 }\end{array}$ & $\begin{array}{c}\text { D5 } \\
\text { PM-17 }\end{array}$ & $\begin{array}{c}\text { D6 } \\
803-1\end{array}$ & $\begin{array}{c}\text { D7 } \\
\text { HAR-4 }\end{array}$ & $\begin{array}{c}\text { D8 } \\
\text { QHP1 }\end{array}$ & $\begin{array}{c}\text { D9 } \\
\text { Ha-335 }\end{array}$ \\
\hline Strain (parent race) & 100 & $\mathrm{~S}$ & $\mathrm{R}$ & $\mathrm{R}$ & $\mathrm{R}$ & $\mathrm{R}$ & $\mathrm{R}$ & $\mathrm{R}$ & $\mathrm{R}$ & $\mathrm{R}$ \\
\hline Strain (parent race) & 710 & $\mathrm{~S}$ & $\mathrm{~S}$ & $\mathrm{~S}$ & $\mathrm{~S}$ & $\mathrm{R}$ & $\mathrm{R}$ & $\mathrm{R}$ & $\mathrm{R}$ & $\mathrm{R}$ \\
\hline Strain (puper race) & 714 & $\mathrm{~S}$ & $\mathrm{~S}$ & $\mathrm{~S}$ & $\mathrm{~S}$ & $\mathrm{R}$ & $\mathrm{R}$ & $\mathrm{R}$ & $\mathrm{R}$ & $\mathrm{S}$ \\
\hline
\end{tabular}

$\mathrm{R}-$ resistant $=$ incompatible interaction

$\mathrm{S}$ - susceptible = compatible interaction (Tourvieille de Labrouhe 1999)

the millet. The aggressiveness criteria (Sakr et al. 2008a; Sakr et al. 2008b) presented in table 1 were measured on sunflower inbred lines carrying different levels of quantitative resistance (Vear et al. 2007; Tourvieille de Labrouhe et al. 2008). Short latent period, high sporulation density and, important reduction in the length of the hypocotyl represent high aggressiveness (Sakr et al. 2008a; 2008b). On the other hand, this strain (super race) was more virulent and did not show any difference of aggressiveness than the other strain (parent race) of virulence profile 710 (Table 1). Damgaard (1999) suggested in a theoretical model the absence of difference of aggressiveness between virulent strain and avirulent. Virulence profile of strains (super race and parent races) was presented in table 2 .

Generally, the super race evolves slowly on genotypes carrying horizontal resistance (Van der Plank 1968; Robinson 1976; Zhan et al. 2002) and it develops difficulty in heterogeneous conditions of plants in mixture (Burdon 1987; Thrall and Burdon 2002). Under our mixture conditions, if super race was produced under $P l$ genes selection pressure, this super race of $P$. halstedii would reproduce on sunflower genotypes carrying different levels of quantitative resistance (highly and moderately), they do not enable it to have a high level of variability. Consequently, the quantity of inoculum would not assure through the period of fungal reproduction in order to develop in next generations. Then, the super race would disappear because his high level of virulence has not a selective advantage for the multiplication and reproduction (Robinson 1976).

\section{Fungus ability to develop more aggressive strains}

Heterogeneous conditions of host plants must lead to decrease pathogen aggressiveness; these are considered as vareital mixture of efficacy control (Villareal and Lannou 2000; de Vallavieille-Pope 2004). Wolfe and Barrett (1980) showed that reduction of symptom severity reaches $50 \%$ in the couple Blumeria graminis/barley in mixture conditions of plants carrying vertical genes resistance. However, several studies found that a mixture of genotypes carrying different levels of quantitative resistance can equally decrease symptom severity caused by pathohens on wheat Pseudcercsporella herportrichoides (Mundt et al. 1995), Mycosphaerella graminicola (Cowger and Mundt 2002) and Phytophthora infestans on potato (Andrivon et al. 2003). Moreover, Finckh and Mundt (1992) showed that mixture of plants carrying qualitative and quantitative resistance reduces $50 \%$ of symptom severity in P. striiformis on the wheat.

Our results (Sakr et al. 2008c) showed that evolution of aggressiveness in P. halstedii populations appears as being linked to the number of diseased plants present in parcels with different strategies of $P l$ gene management (Table 1). The results suggested that the method of $P l$ gene management affects aggressiveness because it determines the number of susceptible plants harboured by the parasite. This results (Sakr et al. 2008c) concerned $P$. halstedii populations of virulence profile 710 .

Under the conditions of our mixture model, the evolution of aggressiveness would be limited by the presence of two forms of inbred resistant inbred lines that would present weak levels of diseased plants needed by the parasite to develop its aggressiveness. 


\section{CONCLUSION}

Research for durable resistance to sunflower downy mildew is new; the best methods are not yet proven. In the experimental conditions of our mixture system, the high level of dilution caused by the presence of vertical genes resistance and different levels of horizontal resistance would assure durable resistance more than a one form of resistance. Because the data obtained from Sakr (2008) and Sakr et al. (2008c) suggest the use only of major gene resistance, whatever the management system, may never give satisfactory durable control. It appears very important to include quantitative resistance in integrated control systems. The ability of $P$. halstedii to develop new virulence and aggressiveness under artificial conditions of infection and selection pressure renders difficult to predict the evolutionary potential of $P$. halstedii under traditional agricultural conditions when the influence of environment plays an important role in pathogenicity evolution and the response of host plant to pathogen. From this study, the mixture of different sources of resistance may assure an acceptable level of durable resistance against sunflower downy mildew, experimental and laboratory tests are necessary in order to validate our mixture model.

\section{ACKNOWLEDGEMENTS}

We would like to thank F. VEAR and M. Zarkawi for critical reading of this manuscript.

\section{REFERENCES}

Albourie J.M, Tourvieille J., Tourvieille de Labrouhe D. 1998. Resistance to metalaxyl in isolates of the sunflower pathogen Plasmopara halstedii. Eur. J. Plant Pathol. 104: 235-242.

Andrivon D., Lucas J.M., Ellisseche D. 2003. Development of natural late blight epidemics in pure and mixed plots of potato cultivars with different levels of partial resistance. Plant Pathol. 52: 586-594.

Bayles R.A., Flath K., Hovmoller M.S., de Vallavieille-Pope C. 2000. Breakdown of the $Y r 17$ resistance to yellow rust of wheat in northern Eur. Agronomie 20: 805-811.

Burdon J.J. 1987. Diseases and Plant Population Biology. Cambridge University Press, Cambridge, 208 pp.

Burdon J.J., Thrall P.H., Ericson L. 2006. The current and future dynamics of disease in plant communities. Ann. Rev. Phytopathol. 44: 19-39.

Cowger C., Mundt C.C. 2002. Effects of wheat cultivars on epidemic progression of Septoria tritici blotch and pathogenicity of Mycosphaerella graminicola. Phytopathology 92: 617-623.

Damgaard C. 1999. Coevolution of a plant host-pathogen genefor-gene system in a metapopulation model without cost of resistance or cost of virulence. J. Theor. Biol. 201: 1-12.

de Vallavieille-Pope C. 2004. Management of disease resistance diversity of cultivars of a species in single fields: controlling epidemics. CR Biologies 327: 611-620.

Delmotte F., Giresse X., Richard-Cervera S., M’Baya J., Vear F., Tourvieille J., Walser P., Tourvieille de Labrouhe D. 2008. Single nucleotide polymorphisms reveal multiple introduc- tions into France of Plasmopara halstedii, the plant pathogen causing sunflower downy mildew. Infection, Genetics, and Evolution (in press).

Dussle C.M., Hahn V., Knapp V., Bauer E. 2004. PlArg from Helianthus argophullus is unlinked to other downy mildew resistance genes in sunflower. Theor. Appl. Genet. 104: 592-600.

Finckh M.R., Mundt C.C. 1992. Stripe rust, and plant competition in wheat cultivar mixtures. Phytopathology 82: 905-913.

Finckh M.R., Wolfe M.S. 1998. Diversification strategies. p. 231259. In: "Proceeding. 1998 The Epidemiology of Plant Diseases" (D.G. Jones, eds.). Chapman and Hall, London.

Flor H.H. 1971. Current status of the gene-for-gene concept. Ann. Rev. Phytopathol. 9: 275-296.

Garrett K.A., Mundt C.C. 1999. Epidemiology in mixed host populations. Phytopathology 89: 984-990.

Garrett K.A., Nelson R.J., Mundt C.C., Chacon G., Jaramillo R.E., Forbes G.A. 2001. The effects of host diversity and other management components on epidemics of potato late blight in the humid highland tropics. Phytopathology 91: 993-1000.

Gout L., Kuhn M.L., Vincenot L., Bernard-Samain S., Cattolico L., Barbetti M., Moreno-Rico O., Balesdent M.H., Rouxel T. 2007. Genome structure impacts molecular evolution at the AvrLm1 avirulence locus of the plant pathogen Leptospaeria maculans. Environ. Microbiol. 9: 2978-2992.

Groenewegen L.J.M., Zadoks J.C. 1979. Exploiting within-field diversity as a defence against cereal diseases: a plea for "poly-genotype" varieties. Indian J. Genet. Plant Breed. 39: 81-94.

Gulya T.J. 2007. Distribution of Plasmopara halstedii races from sunflower around the world. p. 135-142. In: "Advances in Downy Mildew Research" Vol. 3. Proc. of the 2nd International Downy Mildew Symposium. Palcky University in Olomouc and JOLA, v.o.s., Kostelec na Hane, Czech Republic.

Johnson R. 1984. A critical analysis of durable resistance. Ann. Rev. Phytopathol. 22: 309-330.

Joosten M.H.A.J., Cozijnsen T.J., de Wit P.J.G.M. 1994. Host resistance to a fungal tomato pathogen lost by a single base-pair change in an avirulence gene. Nature 367: 384-386.

Joosten M.H.A.J., de Wit P.J.G.M. 1999. The tomato - Cladosporium fulvum interaction: A versatile experimental system to study plant-pathogen interactions. Ann. Rev. Phytopathol. 37: 335-367.

Knops J.M.H., Tilman D., Haddad N.M., Naeem S., Mitchell C.E., Haarsted J., Ritchie M.E., Howe K.M., Reich P.B., Siemann E., Groth J. 1999. Effects of plant species richness on invasion dynamics, disease outbreaks, insect abundance and diversity. Ecology Letters 2: 286-293.

Kolmer J.A. 1993. Selection in a heterogeneous populations of Puccinia recondita f.sp. tritici. Phytopathology 83: 909-914.

Komjati H., Bakonyi J., Spring O., Viranyi F. 2008. Isozyme analysis of Plasmopara halstedii using cellulose-acetate gel electrophoresis. Plant Pathol. 57: 57-63.

Lannou C. 2001. Intrapathotype diversity for aggressiveness and pathogen evolution in cultivar mixtures. Phytopathology 91: 500-510.

Lannou C., Mundt C.C. 1996. Evolution of a pathogen population in host mixtures: simple race-complex race competition. Plant Pathol. 45: 440-453. 
Lannou C., Hubert P., Gimeno C. 2005. Competition and interactions among stripe rust pathotypes in wheat-cultivar mixtures. Plant Pathol. 54: 699-712.

Leach J.E, Cruz C.M.V., Bai J., Leung H. 2001. Pathogen fitness penalty as a predictor of durability of disease resistance genes. Ann. Rev. Phytopathol. 39: 187-224.

McDonald B.A., Linde C. 2002. The population genetics of plant pathogens and breeding strategies for durable resistance. Euphytica 124: 163-180.

Montarry J., Corbiere R., Lesueur S., Glais I., Andrivon D. 2006. Does selection by resistant hosts trigger local adaptation in plant-pathogen systemes? J. Evol. Biol. 19: 522-531.

Mundt C.C. 2002. Use of multiline cultivars and cultivar mixtures for disease management. Ann. Rev. Phytopathol. 40: $381-410$

Mundt C.C., Brophy L.S., Schmitt M.E. 1995. Choosing crop cultivars and cultivar mixtures under low versus high disease pressure: a cause study with wheat. Crop Protect. 14: 509-515.

Murakami J., Hau V.T.B., Mayama S., Tosa Y. 2006. Reduction in aggressiveness among hybrids between host-specific pathotypes of Magnaporthe oryza is caused by reduced ability to overcome adult resistance at the level of penetration. J. Gen. Plant Pathol. 72: 284-291.

Palumbi S.R. 2001. Humans as the world's greatest evolutionary force. Science 293: 1786-1790.

Parlevliet J.E. 2002. Durability of resistance against fungal, bacterial and viral pathogens; present situation. Euphytica 124: 147-156.

Parisi L., Lespinasse Y., Guillaumes J., Kruger J. 1993. A new race of Venturia inaequalis virulent to apples with resistance due to the Vf gene. Phytopathology 83: 533-537.

Radwan O., Bouzidi M.F., Vear F., Phillipon J., Tourvieille de Labrouhe D., Nicolas P., Mouzeyar S. 2002. Identification of non TIR-NBS-LRR markers linked to the PL5/PL8 locus for resistance to downy mildew in sunflower. Theor. Appl. Genet. 106: 14381446

Robinson R.A. 1976. Plant Pathosystems. Academic Press, New York, $184 \mathrm{pp}$.

Sacristan S., Garcia-Arenal F. 2008. The evolution of virulence and pathogenicity in plant pathogen population. Mol. Plant Pathol. (in press).

Sakr N. 2008. Analysis of virulence cost in Plasmopara halstedii (Sunflower downy mildew). Clermont-Ferrand, France: Blaise Pascal University, PhD Thesis, 136 pp.

Sakr N., Ducher M., Tourvieille J., Walser P., Tourvieille de Labrouhe D. 2007. A new methode to obtain monozoosporangial isolates of sunflower downy mildew (Plasmopara halstedii). Cryptogamie, Mycologie 28: 123-131.

Sakr N., Ducher M., Tourvieille J., Walser P., Vear F., Tourvieille de Labrouhe D. 2008a. A method to measure aggressiveness of Plasmopara halstedii (sunflower downy mildew). J. Phytopathol. 157: 133-136.

Sakr N., Ducher M., Tourvieille J., Walser P., Vear F., Tourvieille de Labrouhe D. 2008b. Variation in form and size of Plasmopara halstedii (sunflower downy mildew) zoosporangia. Mycol. Prog. 7 (4): 257265.

Sakr N., Tourvieille J., Walser P., Vear F., Ducher M., Tourvieille de Labrouhe D. 2008c. Can management of $P l$ genes influence on aggressiveness in Plasmopara halstedii (sunflower downy mildew)? p. 115-120. In: Proceedings of 17th International Sunflower Conference, Cordoba, Spain.

Smithson J.B., Lenne J.M. 1996. Varietal mixtures: a viable strategy for sustainable productivity in subsistence agriculture. Ann. Appl. Biol. 128: 127-158.

Spring O., Haas K. 2002. The fatty acid composition of Plasmopara halstedii and its taxonomic significance. Eur. J. Plant Pathol. 108: 263-267.

Thrall P.H., Burdon J.J. 2000. Effect of resistance variation in a natural plant host-pathogen metapopulation on disease dynamics. Plant Pathol. 49: 767-773.

Thrall P.H., Burdon J.J. 2002. Evolution of gene-for-gene systems in meatpopulations: the effect of spatial scale of host and pathogen dispersal. Plant Pathol. 51: 169-184.

Tourvieille de Labrouhe D. 1999. La nouvelle nomenclature des races de Plasmopara halstedii, agent du mildiou du tournesol, appliquée aux races françaises. Oléagineux, Corps Gras, Lipides 6: 219-222.

Tourvieille de Labrouhe D., Mestries E., Walser P. 2005. Quelles perspectives pour la lutte génétique vis-à-vis du mildiou du tournesol? Oleagineux, Corps Gras, Lipides 12: 85-93.

Tourvieille de Labrouhe D., Serre F., Walser P., Roche S., Vear F. 2008. Quantitative resistance to downy mildew (Plasmopara halstedii) in sunflower (Helianthus annuus). Euphytica (in press).

Van den Bosch F., Gilligan C.A. 2003. Measures of durability of resistance. Phyopathology 93: 616-625.

Van der Hoorn R.A.L., De Wit P.J.G.M., Joosten M.H.A. 2002. Balancing selection favors guarding resistance proteins. Trends Plant Sci. 7: 67-71.

Van der Plank J.E. 1968. Disease Resistance in Plants. Academic Press New York and London, 206 pp.

Vear F., Leclercq P. 1971. Deux nouveaux gènes de résistance au mildiou du tournesol. Ann. de l'Amélioration des Plantes 21: 215-255.

Vear F., Serre F., Roche S., Walser P., Tourvieille de Labrouhe D. 2007. Recent research on downy mildew resistance useful for breeding industrial - use sunflower. Helia 30: 45-54.

Villareal L.M.M.A., Lannou C. 2000. Selection for increased spore efficacy by host genetic backround in a wheat powdery mildew population. Phyopathology 90: 1300-1306.

Wolfe M.S. 1985. The current status and prospects of multiline cultivars and variety mixtures for disease resistance. Ann. Rev. Phytopathol. 23: 251-273.

Wolfe M.S., Barrett J.A. 1980. Can we lead the pathogen astray? Plant Dis. 64: 148-151.

Zhu Y., Chen H., Fan J., et al. 2000. Genetic diversity and disease control in rice. Nature 406: 718-722.

Zhan J., Mundt C.C., Hoffer M.E., McDonald B.A. 2002. Local adaptation and effects of host genotype on the rate of pathogen evolution: an experimental test in a plant pathosystem. J. Evol. Biol. 15: 634-647. 


\section{POLISH SUMMARY}

\section{CZY MOŻEMY PODNIEŚĆ TRWAŁA ODPORNOŚĆ NA PLASMOPARA HALSTEDII (MĄCZNIAK RZEKOMY SŁONECZNIKA)?}

Mączniak rzekomy słonecznika wywoływany przez Plasmopara halstedii jest jedną z potencjalnie najważniejszych chorób. Dotychczas, z dobrym skutkiem, wykorzystywano całkowitą odporność uwarunkowaną genem głównym $(P l)$. Jednak od 2000 roku, wraz z pojawieniem się we Francji ośmiu nowych ras grzyba, podjęto bada- nia nad znalezieniem trwalszej odporności. W pracy przedstawiono wyniki badania ewolucji patogeniczności $P$. halstedii w warunkach sztucznej infekcji, przy wykorzystaniu presji infekcyjnej różnych genów Pl. Poza tym symulowano ewolucję wirulencji i agresywności P. halstedii wykorzystując model uwzględniający mieszaniny linii wsobnych posiadających dwa typy odporności, które mogą przyczynić się do trwalszej odporności przeciw tej chorobie. W celu zrozumienia jak patogen rozwija patogeniczność, przedstawiono przykłady współdziałania patogena i rośliny, uwzględniając mieszaniny linii rośliny żywicielskiej. 